\title{
Heat shock protein induction in rat pancreatic islets by recombinant human interleukin $1 \beta$
}

\author{
S.Helqvist ${ }^{1}$, B.S. Polla ${ }^{2}$, J. Johannesen ${ }^{1}$ and J. Nerup ${ }^{1}$ \\ ' Steno Memorial Hospital and Hagedorn Research Laboratory, Gentofte, Denmark \\ ${ }^{2}$ Allergy Unit, University Hospital, Geneva, Switzerland
}

\begin{abstract}
Summary. Interleukin $1 \beta$, potentiated by tumour necrosis factor $\alpha$, is cytotoxic to pancreatic Beta cells in vitro. We have hypothesized that interleukin $1 \beta$ induces oxygen free radicals in Beta cells. Since cytotoxicity induced by free radicals and by heat may activate the same cellular repair mechanism (the heat shock response), the aim of this study was to investigate the pattern of protein synthesis in isolated islets after exposure to interleukin $1 \beta(150 \mathrm{pg} / \mathrm{ml}, 24 \mathrm{~h})$, tumour necrosis factor $\alpha(50 \mathrm{ng} / \mathrm{ml}, 24 \mathrm{~h})$, heat shock $\left(43^{\circ} \mathrm{C}, 30 \mathrm{~min}\right)$ and $\mathrm{H}_{2} \mathrm{O}_{2}$ (0.1 mmol/1, $20 \mathrm{~min})$. By polyacrylamide gel electrophoresis, autoradiography, Western-blot analysis and partial peptide mapping of ${ }^{35} S$-methionine labelled islets, interleukin $1 \beta$ was found to induce a 73 kilodalton protein belonging to the heat shock protein family heat shock protein 70 , a heat shock protein 90 , and haem oxygenase. A minor induction of heat shock protein 73 and haem oxygenase was seen after $\mathrm{H}_{2} \mathrm{O}_{2}$. Interleukin $1 \beta$ did not induce heat shock proteins in rat thy-
\end{abstract}

roid cells, rat mesangial cells or in human monocytes. Tumour necrosis factor $\alpha$ did not induce selective protein synthesis. Pre-exposure of islets to heat, tumour necrosis factor $\alpha$, or $\mathrm{H}_{2} \mathrm{O}_{2}$ did not prevent the impairment of glucose-stimulated insulin release seen after $24 \mathrm{~h}$ of interleukin $1 \beta$ exposure. The data are compatible with free radical induction by interleukin $1 \beta$. However, the heat shock response is not specific for oxidative injury, and previous studies have shown discrepant effects as to a protective effect of free radical scavengers against interleukin $1 \beta$-mediated beta-cytotoxicity. Thus, a role for free radicals in this context is not definitely proven.

Key words: Interleukin $1 \beta$, islets of Langerhans, heat shock proteins, haem oxygenase, free radicals, Type 1 (insulin-dependent) diabetes mellitus.
The cytokine interleukin $1 \beta$ (IL-1), mainly produced by the monocyte/macrophage cell lineage, is cytotoxic to Beta cells in isolated pancreatic islets $[1,2]$. The long-term effects of IL-1 involve decreased islet insulin biosynthesis and release, decreased glucose oxidation, oxygen uptake, protein synthesis and islet content of insulin and DNA [2]. IL-1-exposed islets present signs of Beta-cell necrosis such as condensation of chromatin, vacuolization of the endoplasmic reticulum and cytolysis [3, 4]. Tumour necrosis factor $\alpha$ (TNF) potentiates some of the IL-1 effects, but has no effect on Beta cells in itself [5,6]. Since the first cells to appear in the insulitis process are monocytic cells [7], IL-1 may be responsible for the initial Beta-cell damage eventually resulting in Type 1 (insulin-dependent) diabetes mellitus [8].

Why IL-1 is Beta-cell cytotoxic is not clear. We hypothesized that Beta-cell death was caused by oxidative injury due to IL-1-mediated induction of oxygen free radicals [8]. Eukaryotic and prokaryotic cells possess a stress-response mechanism [9], which is activated under several stress conditions, e. g. exposure of cells to heat, oxygen free radicals, heavy metals, and ultraviolet radiation [9]. A hallmark of this stress response is a decrease of cellular protein synthesis, coinciding with the induction of a specific set of proteins called stress proteins or heat shock proteins (HSPs) [9]. For this cellular response pattern the term "heat shock response" is generally used. HSPs are believed to play a role in repair and protection against cellular stress. HSPs (induced by non-lethal heat shock) protect a TNFsensitive tumour cell line from TNF cytotoxicity [10], and, in turn, oxidative stress can under certain circumstances induce thermotolerance [11]. Moreover, TNF raises a defense against oxidative stress by way of the induction of manganous superoxide dismutase (MnSOD) in several human epithelial cell types [12], and we recently found that IL-1 induces new protein synthesis in rat islets [13]. Against this background we studied the pattern of protein synthesis in islet cells after exposure to IL-1 and/or TNF. The effect was compared to that of heat shock and oxidative stress $\left(\mathrm{H}_{2} \mathrm{O}_{2}\right)$. In addition, we investigated whether pre-exposure 
Table 1. Effects of cytokines, heat shock and $\mathrm{H}_{2} \mathrm{O}_{2}$ on islet function and islet contents of insulin and DNA

\begin{tabular}{llllrr}
\hline & $\begin{array}{l}\text { IRI release to medium } \\
\text { ng/islet } \times 24 \mathrm{~h}\end{array}$ & $\begin{array}{l}\text { IRI secretion } \\
\mathrm{ng} / \mathrm{islet} \times 2 \mathrm{~h}\end{array}$ & $\begin{array}{l}\text { IRI content } \\
\mathrm{ng} / \text { islet }\end{array}$ & $\begin{array}{l}\text { DNA content } \\
\mathrm{ng} / \text { islet }\end{array}$ & $\begin{array}{l}\text { IRI/DNA } \\
\mathrm{ng} / \mathrm{ng}\end{array}$ \\
\hline $\begin{array}{l}\text { Culture condition } \\
\text { IIL-1 } 150 \mathrm{pg} / \mathrm{ml}, 24 \mathrm{~h}\end{array}$ & $54.3 \pm 4.62^{\mathrm{a}}$ & $9.54 \pm 1.17^{\mathrm{a}}$ & $82.1 \pm 4.52^{\mathrm{a}}$ & $102 \pm 5.52$ & $82.1 \pm 4.94^{\mathrm{a}}$ \\
TNF $50 \mathrm{ng} / \mathrm{ml}, 24 \mathrm{~h}$ & $127 \pm 7.82$ & $88.4 \pm 11.5$ & $83.1 \pm 3.29$ & $102 \pm 4.65$ & $83.3 \pm 6.49$ \\
$\mathrm{H}_{2} \mathrm{O}_{2} 0.1 \mathrm{mmol} / \mathrm{m}, 20 \mathrm{~min}$ & - & $108 \pm 17.2$ & $109 \pm 18.3$ & $97.5 \pm 12.0$ & $127 \pm 35.7$ \\
heat shock $43^{\circ} \mathrm{C}, 30 \mathrm{~min}$ & - & $79.7 \pm 12.5$ & $97.2 \pm 8.95$ & $100 \pm 8.97$ & $96.8 \pm 8.70$ \\
\hline
\end{tabular}

Islets were cultured in RPMI 1640 under conditions as noted above. After culture, duplicate groups of 50 islets were incubated in KrebsRinger bicarbonate buffer (KRB) [2] containing $0.2 \%$ bovine serum albumin and $1.67 \mathrm{mmol} / 1$ of glucose. After $1 \mathrm{~h}$ of incubation at $37^{\circ} \mathrm{C}$, the buffer was removed and replaced by $\mathrm{KRB}$ containing $16.7 \mathrm{mmol} / \mathrm{glucose}$. Islets were finally incubated at $37^{\circ} \mathrm{C}$ for $2 \mathrm{~h}$. Data originate from different series of experiments, individually

Table 2. Islet cell synthesis of 32 kilodalton $(\mathrm{kD})$ and $72 / 73 \mathrm{kD}$ proteins during a $4 \mathrm{~h}$ labelling period $\left({ }^{35} \mathrm{~S}\right.$-methionine $)$ after exposure to cytokines and heat shock

\begin{tabular}{|c|c|c|c|}
\hline \multirow[t]{2}{*}{ Culture condition } & $32 \mathrm{kD}$ protein & $72 / 73 \mathrm{kD}$ protein & \multirow[t]{2}{*}{$n$} \\
\hline & \multicolumn{2}{|c|}{ (\% of total protein synthesis) } & \\
\hline Control, $24 \mathrm{in}$ & $0.5 \pm 0.2$ & $0.8 \pm 0.5$ & 23 \\
\hline $\mathrm{IL}-1 \beta 150 \mathrm{pg} / \mathrm{ml}, 24 \mathrm{~h}$ & $7.1 \pm 0.6^{b}$ & $7.4 \pm 0.6^{b}$ & 23 \\
\hline Heat shock, $43^{\circ} \mathrm{C}, 30 \mathrm{~min}$ & $1.2 \pm 0.4$ & $14.1 \pm 2.4^{\mathrm{a}}$ & 6 \\
\hline Heat shock before $I L-1 \beta$ & $8.7 \pm 1.1^{\mathrm{a}}$ & $2.5 \pm 1.9$ & 6 \\
\hline TNF $\alpha 50 \mathrm{ng} / \mathrm{ml}, 24 \mathrm{~h}$ & $0.6 \pm 0.3$ & $0.4 \pm 0.4$ & 8 \\
\hline TNF $\alpha+$ IL $-1 \beta$ & $7.7 \pm 1.2^{\mathrm{a}}$ & $7.3 \pm 0.3^{a}$ & 5 \\
\hline TNF $\alpha$ before IL-1 $\beta$ & $7.3 \pm 0.1^{\mathrm{a}}$ & $7.3 \pm 0.6^{\mathrm{a}}$ & 7 \\
\hline $\mathrm{H}_{2} \mathrm{O}_{2} 0.1 \mathrm{mmol} / /, 20 \mathrm{~min}$ & $1.8 \pm 0.9$ & $2.0 \pm 1.0$ & 9 \\
\hline $\mathrm{H}_{2} \mathrm{O}_{2}$ before IL- $1 \beta$ & $6.8 \pm 0.5^{a}$ & $6.4 \pm 0.5^{a}$ & 5 \\
\hline
\end{tabular}

Quantification of protein synthesis was performed by densitometry of autoradiograms of labelled islet cell proteins. Data (mean \pm SEM) express the percentage of total islet cell protein synthesis.

$n$ is number of experiments. ${ }^{\mathrm{a}}$ and ${ }^{\mathrm{b}}$ denote $p<0.05$ and $p<0.01$, respectively, compared with control culture.

IL-1 $\beta=$ interleukin $1 \beta$, TNF = tumour necrosis factor

of islets to heat, oxidative stress $\left(\mathrm{H}_{2} \mathrm{O}_{2}\right)$ or TNF would modulate the effects of IL-1 on Beta cells.

\section{Materials and methods}

\section{Reagents}

Recombinant human interleukin $1 \beta$ (rIL-1 $\beta$ ) was provided by Novo Nordisk Ltd., (Bagsværd, Denmark). The specific activity was $400 \mathrm{U} / \mathrm{ng}$ [14]; Recombinant human tumour necrosis factor $\alpha$ (TNF) was purchased from Genzyme, (Boston, Mass., USA). The specific activity (cytotoxicity of L929 cells in the presence of ActinomycinD) was $2 \times 10^{7} \mathrm{U} / \mathrm{mg} . \mathrm{H}_{2} \mathrm{O}_{2}$ and sodium-dodecyl-hydrogensulphate (SDS) were purchased from Merck, (Darmstadt, FRG). 2-Mercapto-ethanol and Nonidet P40 were obtained from Fluka AG, (Buchs, Switzerland) and BDH Chemicals, (Poole, UK), respectively. ${ }^{35} \mathrm{~S}$ Methionine and Amplify were purchased from Amersham International (Amersham, UK). RPMI 1640 culture medium was purchased from Gibco (Paisley, Scotland).

\section{Islet isolation and culture}

Pancreatic islets from 5-7 day old outbred Wistar rats were isolated after collagenase exposure to the pancreas as previously described [15]. After pre-cuiture for 5 days in RPMI containing $10 \%$ newborn performed in a paired design and are therefore presented as percentages (mean $\pm S E M$ ) of corresponding control islets cultured in RPMI 1640 at $37^{\circ} \mathrm{C}$.

$n=6$ for all experiments; ${ }^{a}$ denotes $p<0.05$ vs $100 \%$ (Wilcoxon's matched pairs test).

IRI = immunoreactive insulin, $\mathrm{TNF}=$ tumour necrosis factor, rIL$1 \beta=$ recombinant human interleukin $1 \beta$

calf serum islets were cultured in RPMI 1640 containing $11 \mathrm{mmol} / 1$ glucose plus $0.5 \%$ normal human serum. The following protocols for islet culture were followed: rIL-1 $150 \mathrm{pg} / \mathrm{ml}, 24 \mathrm{~h} ;$ TNF $50 \mathrm{ng} / \mathrm{ml}$, $24 \mathrm{~h}$; Heat shock $\left(43^{\circ} \mathrm{C}\right), 30 \mathrm{~min} ; \mathrm{H}_{2} \mathrm{O}_{2} 0.1 \mathrm{mmol} / \mathrm{l}, 20 \mathrm{~min}$. To study the influence of islet pre-exposure to TNF and $\mathrm{H}_{2} \mathrm{O}_{2}$ on the rIL-1 $1 \beta$ effect, islets were carefully washed twice after TNF or $\mathrm{H}_{2} \mathrm{O}_{2}$ exposure before being transferred to rlL-1 $\beta$-containing medium. In experiments studying the rIL-1 $\beta$ effects after heat shock, islets were transferred to rIL-1 $\beta$ containing medium immediately after heat shock. The reason for exposing islets to IL-1 $\beta$ immediately after the heat shock procedure was that the initial effect of rIL-1 $\beta$ is stimulatory rather than cytotoxic to islet cells [8]. Thus, islets were considered to be sufficiently able to synthesize HSPs after heat shock during rIL$1 \beta$ exposure.

After culture, duplicate groups of 50 islets were washed once and incubated as described [2] in Krebs-Ringer bicarbonate buffer (KRB) containing $0.2 \%$ bovine serum albumin and $1.67 \mathrm{mmol} / \mathrm{l}$ of glucose. After $1 \mathrm{~h}$ of incubation at $37^{\circ} \mathrm{C}$, the buffer was removed and replaced by $\mathrm{KRB}$ containing $16.7 \mathrm{mmol} / \mathrm{l}$ glucose. Islets were finally incubated at $37^{\circ} \mathrm{C}$ for $2 \mathrm{~h}$. Insulin in $\mathrm{KRB}$ containing $16.7 \mathrm{mmol} / \mathrm{l}$ glucose was measured by RIA [16]. Subsequently, islets were washed once and suspended in distilled water. After ultrasonication, insulin and DNA [17] contents were measured in the aqueous islet cell homogenates to determine islet insulin and DNA contents.

\section{Preparation of rat thyroid cells}

The thyroid gland was excised from normal adult Wistar rats. After cutting the gland into pieces (diameter $1-2 \mathrm{~mm}$ ), the tissue was exposed to collagenase $(1 \mathrm{mg} / \mathrm{ml})$ and dispase $(1.2 \mathrm{U} / \mathrm{ml})$ and shaken rapidly for $1 \mathrm{~h}$ at $37^{\circ} \mathrm{C}$. The subsequent washing procedure (four times) and cell culture were performed in media identical to those used for islets. Cells were tested for identity and function by measurement of the medium accumulation of thyroxin (data not shown). To maintain thyroid cell activity the following agents (all purchased from Sigma Chemical Co., St. Louis, Mo., USA) were added to the culture medium: hydrocortisone $\left(10^{-1} \mathrm{~mol} / \mathrm{l}\right)$, transferrin $(5 \mu \mathrm{g} / \mathrm{ml})$, somatostatin $(10 \mathrm{ng} / \mathrm{ml})$, glycyl-histidyl-lysin-acetate $(20 \mathrm{ng} / \mathrm{ml})$, $\mathrm{TSH}(1 \mathrm{mU} / \mathrm{ml})$ and insulin $(10 \mu \mathrm{g} / \mathrm{ml})$. The cells were pre-cultured for six days before exposure to $150 \mathrm{pg} / \mathrm{ml}$ of rIL-1 $\beta$ for one or three days.

\section{SDS polyacrylamide gel electrophoresis ( $S D S-P A G E$ ), autoradiography, Western-blot analysis, and partial peptide mapping}

Before islet protein separation, groups of 125 islets were washed twice in methionine-free RPMI 1640 and kept at $37^{\circ} \mathrm{C}$ for $15 \mathrm{~min}$ in methionine-free RPMI 1640. Thereafter, islets were transferred to and kept at $37^{\circ} \mathrm{C}$ for $4 \mathrm{~h}$ in $0.5 \mathrm{ml}$ of RPMI 1640 with the addition of 


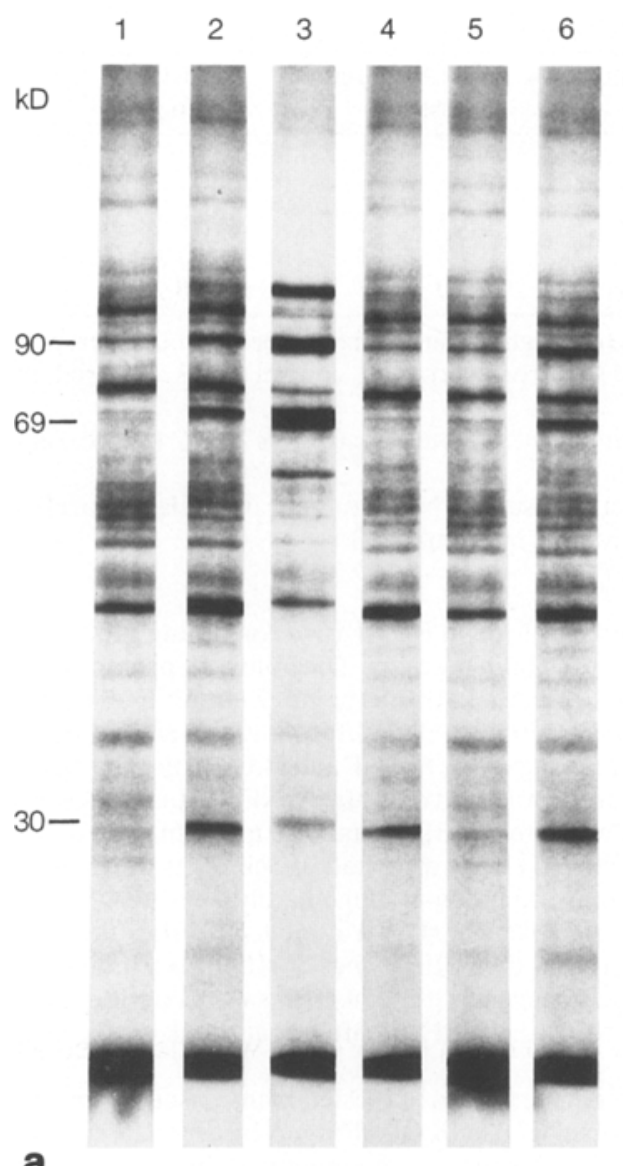

a

Fig. 1 a,b. SDS-PAGE (10\% gels) and autoradiography of lysed, ${ }^{35} \mathrm{~S}-$ methionine-labelled, isolated and pre-cultured rat pancreatic islets [2]. Before labelling for $4 \mathrm{~h}$, islets were kept under control culture conditions ( $\mathbf{a}$ and $\mathbf{b}$, lane 1 ) for 24 h or were exposed to recombinant human interleukin $1 \beta$ (rIL-1 $\beta$ ) tumour necrosis factor $\alpha$ (TNF $\alpha$ ), heat shock or $\mathrm{H}_{2} \mathrm{O}_{2}$ according to the following protocol: rIL-1 $\beta$

$0.001 \mathrm{mCi}{ }^{35} \mathrm{~S}$-methionine per islet. SDS-PAGE was performed according to Laemmli [18]: islets were washed in TRIS-buffer, and immediately afterwards exposed to boiling 2-Mercaptoethanol (1\%) and SDS $(0.3 \%)$. Nonidet P40 (1.5\%) dissolved in glycin-buffer ( $\mathrm{pH}$ 8.8 ) was finally added. After addition of SDS sample buffer, aliquots of islet proteins were separated on $0.5 \mathrm{~mm} \mathrm{10 \%} \mathrm{SDS-PAGE} \mathrm{gels.}$ After gel exposure for $20 \mathrm{~min}$ to Amplify, gels were dried, and autoradiography and densitometry were performed. Thyroid cells were treated identically to islets.

Western-blot analysis was performed with a mouse monoclonal anti-human HSP70 [19] and revealed by Auroprobe BLplus Immunogold reagent and intense silver enhancement system (Janssen Pharmaceutica, Beerse, Belgium) or by peroxidase conjugate mouse $\operatorname{IgG}$ (Sigma).

Partial peptide mapping was performed as previously described [20]; in short, an excised gel slice, containing the protein in question, was exposed to N-chlorosuccinimide, which selectively cleaves tryptophanyl peptide bonds in proteins. The protein product was subsequently re-analysed by SDS-PAGE and autoradiography.

\section{Statistical analysis}

Data are means \pm SEM. For each experimental condition, islets used for functional studies and protein synthesis analysis originated from the same batch of islets. Data originating from two series of experiments presented in Table 3 show some differences as to the islet
$150 \mathrm{pg} / \mathrm{ml}, 24 \mathrm{~h}$; TNF $50 \mathrm{ng} / \mathrm{ml}, 24 \mathrm{~h}$; Heat shock: $43^{\circ} \mathrm{C}, 30$ min. $\mathrm{H}_{2} \mathrm{O}_{2}$ : $0.1 \mathrm{mmol} / \mathrm{h}, 20 \mathrm{~min}$. $\mathbf{a}$ and $\mathbf{b}$, lane 2: $\mathrm{rIL}-1 \beta ; \mathbf{a}$, lane 3 ; heat shock; $\mathbf{a}$, lane 4: heat shock before rIL-1 $\beta$; a, lane 5: TNF $\alpha$; a, lane 6: rIL-1 $\beta+$ TNF $\alpha ; \mathbf{b}$, lane 3 : TNF $\alpha$ before $24 \mathrm{~h}$ control culture; $\mathbf{b}$, lane 4 : TNF $\alpha$ before rIL-1 $;$; b, lane $5: \mathrm{H}_{2} \mathrm{O}_{2}$ before $24 \mathrm{~h}$ control culture; $\mathbf{b}$, lane 6 : $\mathrm{H}_{2} \mathrm{O}_{2}$ before rIL-1 $\beta ; \mathbf{b}$, lane $7: \mathrm{H}_{2} \mathrm{O}_{2}$

content of insulin and DNA, presumably due to variability among islet preparations; therefore, all conclusions in this study originate from experiments performed in a paired design. Wilcoxon's matched pairs test was used for statistical analysis with $p<0.05$ as the level of significance.

\section{Results}

Exposure for $24 \mathrm{~h}$ to $150 \mathrm{pg} / \mathrm{ml} \mathrm{rIL}-1 \beta$ caused approximately $50 \%$ reduction in insulin release to the medium during rIL-1 $\beta$ exposure and approximately $90 \%$ reduction of insulin release during a subsequent glucose challenge (exposure to KRB with $16.7 \mathrm{mmol} / \mathrm{l}$ of glucose) (Table 1). Islet insulin content was slightly, but significantly, decreased; islet DNA content was not influenced by rIL-1 $\beta$ (Table 1 ). TNF, $\mathrm{H}_{2} \mathrm{O}_{2}$, and heat shock did not significantly influence any of the above parameters (Table 1 ).

Afterislet exposure torIL-1 $\beta$, the synthesis of three proteins of 32,73 , and 90 kilodalton $(\mathrm{kD})$ were induced or enhanced (Fig. 1, Table 2). By Western-blot analysis the $73 \mathrm{kD}$ protein was identified as a protein belonging to the HSP70 family (Fig. 2). By exposing the $32 \mathrm{kD}$ protein to $\mathrm{N}$ - 

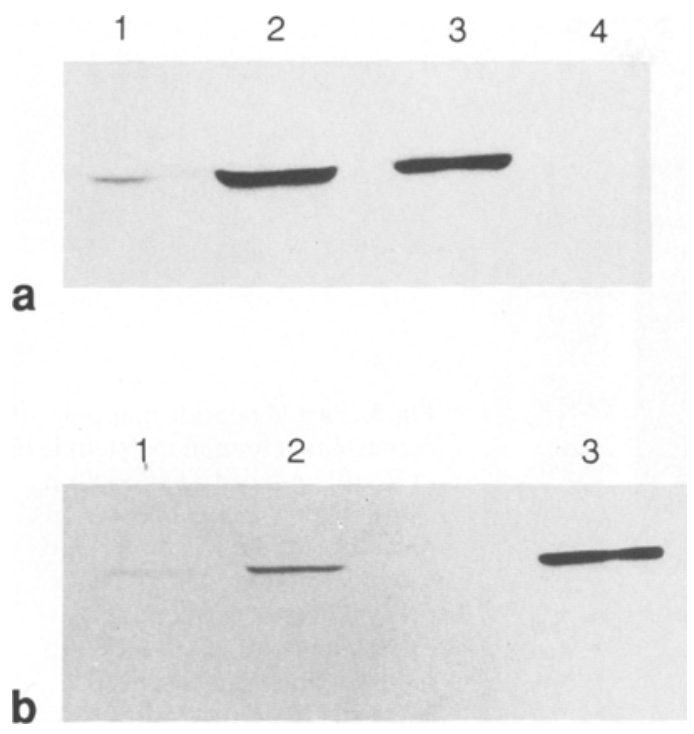

Fig. 2 a, b. Rat islets (a, lane $1 ; \mathbf{b}$, lane 1 and 2 ) were exposed to recombinant human interleukin $1 \beta(\mathbf{a}$, lane $1 ; \mathbf{b}$, lane 2$)$ or maintained under control conditions (b, lane 1 ) as described, then lysed and proteins resolved on $10 \%$ one dimensional polyacrylamide gels. Western blotting was performed with a mouse monoclonal anti-human heat shock protein (HSP)70 [29] and revealed by Auroprobe BLplus Immunogold reagent and intense silver enhancement system (a) or by peroxidase conjugate mouse $\operatorname{IgG}(\mathbf{b})$. Lane 2: a rat mesangial cells, heat shock; lane 3: a and b U937 cells (a human premonocytic line), heat shock; lane 4: a U937 cells, control. Note that the monoclonal antihuman HSP70 did not react at all with control U937 (a, lane 4) cells, whereas it did with control islet cells (b, lane 1). The figures presented are representative of four separate experiments

chloro-succinimide, three distinct cleavage products of approximately 26,24 , and $12 \mathrm{kD}$ were obtained (Fig. 3), a pattern characteristic of haem oxygenase $[20,21]$. The molecular weight of the rIL-1 $\beta$ induced $90 \mathrm{kD}$ protein was identical to that of a $90 \mathrm{kD}$ protein induced after heat shock before labelling. Additionally, heat shock induced HSPs of $32,65,72,73$, and $110 \mathrm{kD}$ (Fig. 1). After exposure of islets to
$0.1 \mathrm{mmol} / 1$ of $\mathrm{H}_{2} \mathrm{O}_{2}$ for $20 \mathrm{~min}$ before labelling, the synthesis of the 32 and $73 \mathrm{kD}$ was slightly enhanced (Fig.1, Table 2). TNF did not induce selective protein synthesis (Fig. 1, Table 2). Pre-exposure of islets to heat suppressed the rIL-1 $\beta$-mediated induction of the 73 and $90 \mathrm{kD}$ proteins, whereas the induction of the $32 \mathrm{kD}$ protein was unchanged (Fig. 1, Table 2). Pre-exposure of islets to TNF or $\mathrm{H}_{2} \mathrm{O}_{2}$ did not influence the rIL-1 $\beta$-mediated induction of protein synthesis. Pre-exposure of islets to heat shock, TNF or $\mathrm{H}_{2} \mathrm{O}_{2}$ neither significantly prevented nor potentiated the rIL-1 $1 \beta$ effect on parameters of Beta-cell function and islet content of insulin and DNA (Table 3 ).

$\mathrm{rIL}-1 \beta$ did not induce selective protein synthesis in thyrocytes (Fig.4).

\section{Discussion}

The present study demonstrated that rIL-1 $\beta$ activates a heat shock response in rat islets, under conditions where rIL-1 $\beta$ is strongly inhibitory to glucose-stimulated insulin release. The three $\mathrm{rIL}-1 \beta$-induced stress proteins had molecular weights of 90,73 and $32 \mathrm{kD}$. Our preliminary finding of rIL-1 $\beta$ also inducing a $80 \mathrm{kD}$ protein [13] was not confirmed in this study, presumably due to a former misinterpretation of the molecular weight of an rIL- $1 \beta$ induced $90 \mathrm{kD}$ protein. The $73 \mathrm{kD}$ protein was identified as a protein belonging to the HSP70 family, the $32 \mathrm{kD}$ as haem oxygenase, and the $90 \mathrm{kD}$ protein had the same molecular weight as that of one of the proteins induced by heat shock. Haem oxygenase is induced by oxidative stress, but also by ultraviolet irradiation, and sodium arsenite in human cells $[20,21]$. Further, haem oxygenase is a heat shock protein in the rat [22]. The heat shock response induced by rIL-1 $\beta$ (and $\mathrm{H}_{2} \mathrm{O}_{2}$ ) had distinct characteristics compared to that induced by heat: The total amount of stress protein synthesis was smaller after rIL-1 $\beta$ (and $\mathrm{H}_{2} \mathrm{O}_{2}$ ), the HSPs 65, 72, and 110 were not detected after exposure to rIL-1 $\beta$, whereas rIL-1 $\beta$ caused a more

Table 3. Influence of pre-exposure of rat islets to heat shock, tumour necrosis factor (TNF) and $\mathrm{H}_{2} \mathrm{O}_{2}$ on recombinant human interleukin-1 $\beta$ $(\mathrm{rIL}-1 \beta)$ effects on rat islets

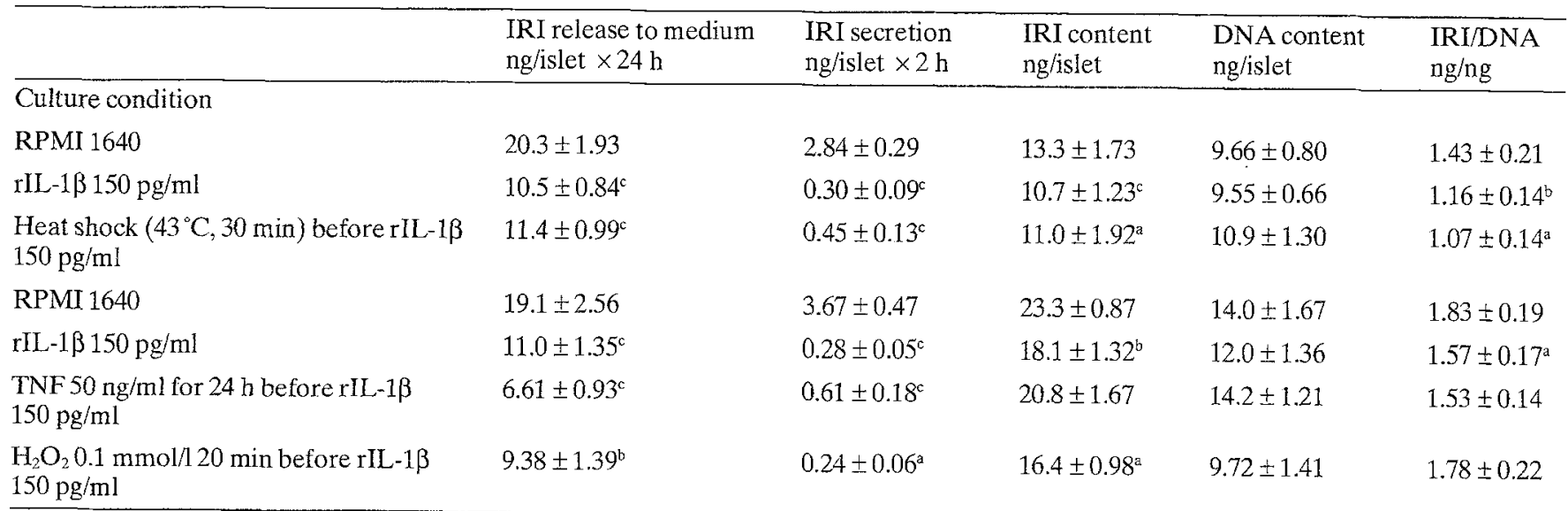

Data are given for two sets of experiments. Islets were cultured for $24 \mathrm{~h}$ in RPMI 1640 with or without the addition of rIL-1 3 preceded by heat shock or exposure to $\mathrm{H}_{2} \mathrm{O}_{2}$ and TNF as indicated above. Islets were subsequently treated as described under Table 1. Data are

means $\pm \mathrm{SEM}, n=6-8 .{ }^{\mathrm{a}, \mathrm{b}, \mathrm{c}}$ denote $p<0.05,0.02,0.01$, respectively, for a chance difference vs control islets cultured without rIL- $1 \beta$ (Wilcoxon's matched pairs test). IRI = immunoreactive insulin 


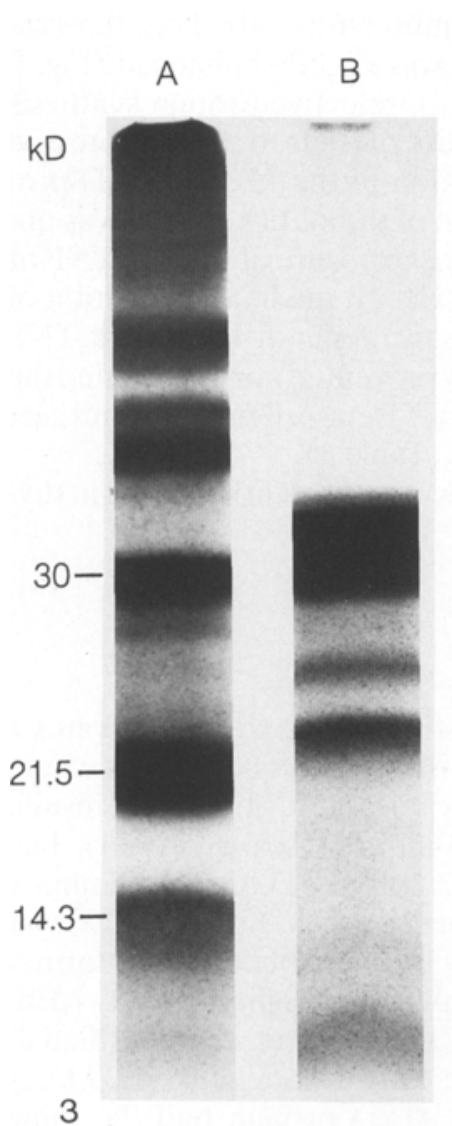

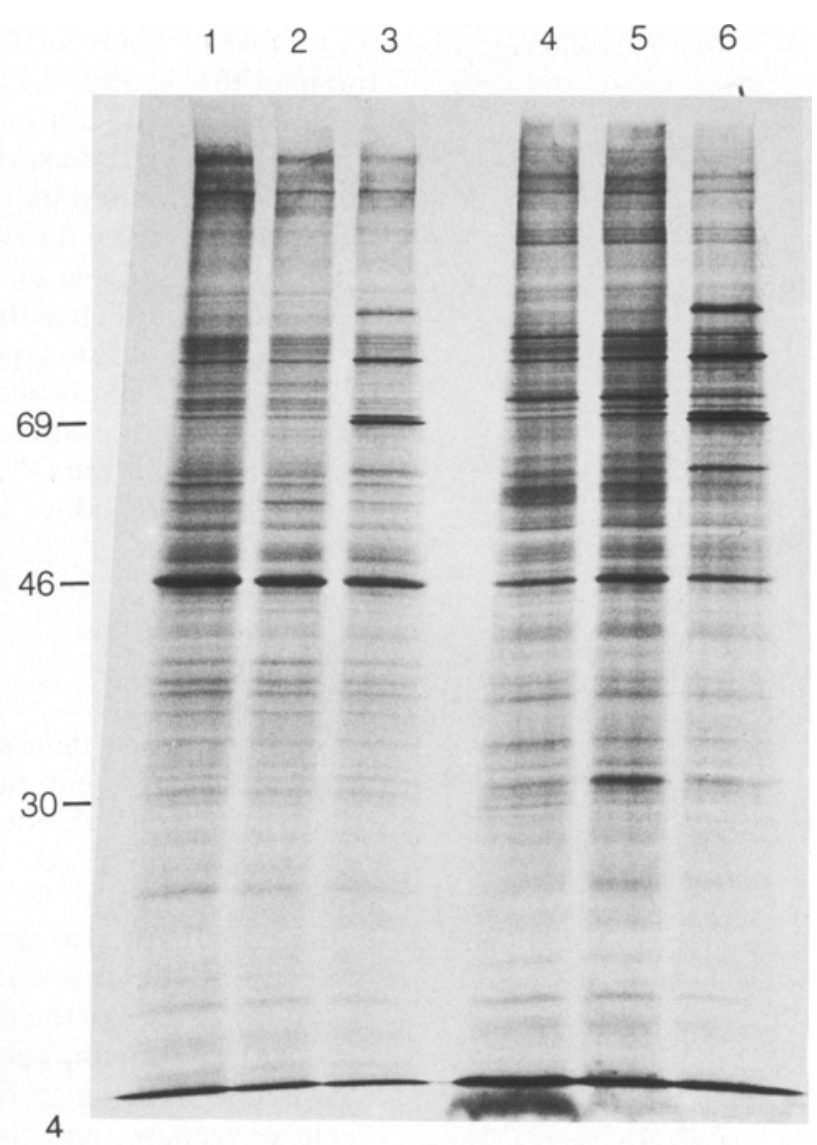

Fig. 3. Partial peptide mapping of recombinant human interleukin $1 \beta$ ( rIL-1 $\beta$ ) induced 32 kilodalton (kD) protein. Lane A represents proteins with known molecular weights (marker), lane $B$ (representative of two separate experiments) represents rIL-1 $\beta$ induced, $\mathrm{N}$-chlorosuccinimide exposed $\mathrm{rIL}-1 \beta$ induced $32 \mathrm{kD}$ protein

Fig.4. SDS-PAGE (10\% gels) and autoradiography of lysed, ${ }^{35} \mathrm{~S}$-methionine-labelled rat thyrocytes (lane 1-3) and islets (lane 4-6) cultured for $24 \mathrm{~h}$ with and without $150 \mathrm{pg} / \mathrm{ml}$ of rIL-1 $\beta$. Lane 1: control culture; lane 2: rIL-13; lane 3: heat shock; lane 4: control culture; lane 5 : $x \mathrm{IL}-1 \beta$; lane 6: heat shock pronounced induction of haem oxygenase. These different patterns of the heat shock response are in accordance with previous observations of oxidative injury inducing a heat shock response different from that induced by heat [23]. Although not specific for oxidative injury, the islet cell heat shock response induced by rIL-1 $\beta$ may reflect the induction of free radicals. HSP induction by $\mathrm{rIL}-1 \beta$ was not seen in rat thyrocytes, rat mesangial cells (not shown) and normal human monocytes (not shown), all cells which are IL-1-responsive, but not susceptible to IL-1-mediated cytotoxicity. This is in agreement with previous studies showing that neither IL-1 nor TNF induced HSP synthesis in fibroblasts, Hep G2 and U937 cells [24], suggesting the activation of a unique response to IL-1 in islet cells.

At the chosen experimental conditions, pre-exposure of islets to neither heat, $\mathrm{H}_{2} \mathrm{O}_{2}$ nor TNF caused protection against or potentiation of the rIL- $1 \beta$ effect on glucosestimulated insulin release (Table 2 ), although heat-induced HSPs were still present (demonstrable by Westernblot) in islets $24 \mathrm{~h}$ after the heat shock procedure (not shown). However, when islets were pre-exposed to heat before the $24 \mathrm{~h}$ period of rIL- $1 \beta$ exposure, less induction of the 73 and $90 \mathrm{kD}$ protein was seen after rIL- $1 \beta$ exposure. This suggests that the presence of heat-induced high molecular weight HSPs may generate a negative feed-back on rIL-1 $\beta$-mediated HSP synthesis. It could also be considered that the immediate addition of rIL-1 $\beta$ after heat shock would prevent the HSP synthesis after heat shock. However, HSP induction by heat during the first $4 \mathrm{~h}$ after heat shock was not influenced by the presence of rIL-1 $\beta$ (not shown). Since heatshock pre-exposure suppressed the rIL-1 $\beta$-induced high molecular weight HSP synthesis, but not the inhibitory effect on insulin secretion, the enhanced synthesis of these HSPs might not be causally related to the toxic effect of rIL-1 $\beta$. Further, that HSPs did not protect against rIL-1 $\beta$ may suggest that there is no causal relationship between the stress proteins and the cytotoxic rIL-1 $\beta$ effect, thus maybe speaking against a role for oxygen free radicals.

The oxygen free radical species $\mathrm{O}_{2}-$ and $\mathrm{H}_{2} \mathrm{O}_{2}$ are produced during oxidative metabolism in the mitochondria during electron transport [25]. We recently demonstrated that $\mathrm{rIL}-1 \beta$ increases the cytosolic concentration of free sodium in islet cells [26], possibly by the activation of the plasma membrane $\mathrm{Na}^{+} / \mathrm{H}^{+}$exchange, which, in human neutrophils (however not yet demonstrated in islet cells), leads to intracellular alkalinization and increased $\mathrm{O}_{2}{ }^{-}$ generation [27]. In analogy, rIL-1 $\beta$ increases oxidative metabolism in short-term rIL-1 $\beta$-exposed islet cells [28], and the likely point of rIL-1 $\beta$-mediated cy totoxicity (longterm rIL-1 $\beta$ exposure) is the mitochondria [4]. Protection from oxygen free radical toxicity requires antioxidants such as superoxide dismutase (SOD), catalase, and glutathione peroxidase (GPO) [29, 30]. Compared to other cell types, islet cells contain small amounts of the oxygen free radical scavengers MnSOD and GPO [31], of which MnSOD is predominantly located to the mitochondria $[29,30]$. Accordingly, islets were found to be most sensitive among different tissues examined for sensitivity to peroxide toxicity [32]. Thus, if $\mathrm{rIL}-1 \beta$ induces oxygen free 
radicals in Beta cells, the Beta-cell cytotoxicity of rIL-1 $\beta$ may reflect insufficient capability of these cells to produce protective proteins that are normally constitutively expressed or inducible. Consequently, Beta cells exposed to rIL-1 $\beta$ may mount an alternative response (HSP and haem oxygenase synthesis) instead of the normal activation of MnSOD and glutathione peroxidase. In this case, Beta-cell survival will be highly dependent on an efficient heat shock response.

Other approaches have been taken as to the investigation of the hypothesis of oxygen free radicals being responsible for cytokine-mediated Beta-cell injury. Studies by others $[4,33-35]$ on the effect of scavengers of free radicals have given conflicting results, may be due to differences in the type and concentration of cytokines used, islet cell exposure time, and the islet cell preparation used.

Since proteins of the HSP70 family are considered important for cellular defense and repair, HSPs may be important determinants for Beta-cell destruction in Type 1 diabetes. In this context it is of interest that genes coding for the major inducible HSP70 in man and rat are located among the genes of the major histocompatibility complex (MHC) $[36,37]$. A strong association between certain MHC genes and the susceptibility to develop Type 1 diabetes exists [38]. Thus, an HSP70 gene polymorphism [39] might be related to differences in Beta-cell capability of defense against IL-1, and might, through linkage disequilibrium between HSP70 genes and MHC-related Type 1 diabetes susceptibility genes like DQw8 [40] and the TNF $\beta 10.5$ kilobase allele [39], quantitatively contribute to the susceptibility to Type 1 diabetes.

In conclusion, the induction of HSPs in islet cells by rIL-1 $\beta$ is compatible with an oxidative injury to islet cells. However, since the heat shock response is not specific for oxidative injury and since free radical scavengers have not been unequivocally shown to protect against $\mathrm{rIL}-1 \beta$, the role for oxygen free radicals in beta-cytotoxicity by rIL-1 $\beta$ is still not definitely proven.

Acknowledgements. We thank Ms. B. Born for technical assistance. The work was supported by the Arvid Nilsson Foundation ( $\mathrm{SH}$ ), the Danish Diabetes Association (SH), The Swiss National Science Foundation (3.960.0.87, BSP), LF Foght's Foundation (JJ), and Novo-Nordisk. SH is a recipient of a Research Fellowship from the Juvenile Diabetes Foundation, New York.

\section{References}

1. Bendtzen K, Mandrup-Poulsen T, Nerup J, Nielsen JH, Dinarello CA, Svenson M (1986) Cytotoxicity of human pI 7 Interleukin-1 for pancreatic islets of Langerhans. Science 232: 1545-1547

2. Sandler S, Andersson A, Hellerström C (1987) Inhibitory effects of interleukin-1 on insulin secretion, insulin biosynthesis, and oxidative metabolism of isolated rat pancreatic islets. Endocrinology 121: 1424-1431

3. Mandrup-Poulsen T, Egeberg J, Nerup J, Bendtzen K, Nielsen JH, Dinarello CA (1987) Ultrastructural studies of time course and cellular specificity of interleukin-1 mediated islet cytotoxicity. Acta Path Microbiol Immunol Scand (C) 95: 55-63

4. Sandler S, Bendtzen K, Borg LAH, Eizirik DL, Strandell E, Welsh N (1989) Studies on the mechanisms causing inhibition in rat pancreatic islets exposed to human interleukin-1 $\beta$ indicate a perturbation in the mitochondrial function. Endocrinology 124: 1492-1501

5. Mandrup-Poulsen T, Bendtzen K, Dinarello CA, Nerup J (1987) Human tumor necrosis factor potentiates human interleukin 1-mediated rat pancreatic beta-cell toxicity. J Immunol 139: 4077-4082

6. Eizirik DL (1988) Interleukin 1-induced impairment of pancreatic islet oxidative metabolism of glucose is potentiated by tumor necrosis factor. Acta Endocrinol (Copenh) 119: 321-325

7. Vorbij HAM, Jeucken PHM, Kabel PJ, de Haan M, Drexhage HA (1989) Dendritic cells and scavenger macrophages in pancreatic islets of prediabetic BB rats. Diabetes 38: 1623-1629

8. Nerup J, Mandrup-Poulsen T, Mølvig J, Helqvist S, Wogensen LD, Egeberg J (1988) Mechanisms of pancreatic $\beta$-cell destruction in Type I diabetes. Diabetes Care 11 [Supp1 1]: 16-23

9. Kaufmann SHE (1990) Heat shock proteins and the immune response. Immunol Today 11: 129-136

10. Kusher DI, Guding LR (1989) Heat shock alters cell response to tumor necrosis factor. Cytokine 1: 110

11. Polla BS, Healy AM, Wonjo WC, Krane SM (1987) Hormone 1 $\alpha, 25$-dihydroxyvitamin $D_{3}$ modulates heat shock response in monocytes. Am J Physiol 252; C640-C649

12. Wong GWH, Goeddel DV (1988) Induction of manganous superoxide dismutase by tumor necrosis factor: possible protective mechanism. Science 242: 941-944

13. Helqvist S, Hansen BS, Johannesen J, Andersen HU, Nielsen JH, Nerup J (1989) Interleukin 1 induces new protein formation in isolated islets of Langerhans. Acta Endocrinol (Copenh) 121: 136-140

14. Dalbøge H, Bayne S, Christensen T, Hejnæs KR (1989) Cloning and expression of an interleukin- $1 \beta$ precursor and its conversion to interleukin-1 $\beta$. FEBS Lett 246: 89-93

15. Brunstedt J, Nielsen JH, Lernmark $\AA$ and the Hagedorn Study Group (1984) Isolation of islets from mice and rats. In: Larner J, Pohl SL (eds) Methods in diabetes research, vol 1 (Laboratory methods, part C). Wiley \& Sons, New York, pp 254-258

16. Heding L (1972) Determination of total serum insulin (IRI) in insulin-treated diabetic patients. Diabetologia 8: 260-266

17. Green IC, Taylor KW (1972) Effects of pregnancy in the rat on the size and the insulin secretory response of the islet of Langerhans. J Endocrinol 54: 317-325

18. Laemmli UK (1970) Cleavage of structural proteins during the assembly of the head of the bacteriophage T4. Nature 227: 680685

19. Welch WJ, Suhan JP (1986) Cellular and biochemical events in mammalian cells during and after recovery from physiological stress. J Cell Biol 103: 2035-2052

20. Keyse SM, Tyrell RM (1987) Both near ultraviolet radiation and the oxidizing agent hydrogen peroxide induce a $32-\mathrm{kDa}$ stress protein in normal human skin fibroblasts. J Biol Chem 262: $14821-14825$

21. Keyse SM, Tyrrell RM (1989) Heme oxygenase is the major 32$\mathrm{kDa}$ stress protein induced in human skin fibroblasts by UVA radiation, hydrogen peroxide, and sodium arsenite. Proc Natl Acad Sci USA 86: 99-103

22. Shibahara S, Müller RM, Taguchi H (1987) Transcriptional control of rat heme oxygenase by heat shock. J Biol Chem 262: 12889-12892

23. Donati YRA, Slosman DO, Polla BS (1990) Oxidative injury and the heat shock response. Biochem Pharmacol 40: 2571-2577

24. Kaur P, Welch WJ, Saklatvala J (1989) Interleukin 1 and tumour necrosis factor increase phosphorylation of the small heat shock protein. FEBS Lett 258: 269-273

25. Freeman BA, Crapo JD (1982) Biology of disease. Free radicals and tissue injury. Lab Invest 47: 412-426

26. Helqvist S, Bouchelouche PN, Johannesen J, Nerup J (1990) Interleukin $1 \beta$ increases the cytosolic free sodium concentration in isolated rat islets of Langerhans. Scand J Immunol 32: 53-58

27. Simchowitz L (1985) Intracellular pH modulates the generation of superoxide radicals by human neutrophils. J Clin Invest 76 : 1079-1089 
28. Eizirik DL, Sandler S (1989) Human interleukin-1ß induced stimulation of insulin release from rat pancreatic islets is accompanied by an increase in mitochondrial oxidative events. Diabetologia 32: 769-773

29. Touati D (1988) Molecular genetics of superoxide dismutases. Free Radical Biol Med 5: 393-402

30. Hassan HM (1988) Biosynthesis and regulation of superoxide dismutases. Free Radical Biol Med 5: 377-385

31. Asayama K, Kooy NW, Burr IM (1986) Effect of vitamin E deficiency on insulin secretory reserve and free radical scavenging systems in islets. J Lab Clin Med 107: 459-464

32. Malaisse WJ, Malaisse-Lagae F, Sener A, Pipeleers DG (1982) Determinants of the selective toxicity of alloxan to the pancreatic B cell. Proc Natl Acad Sci USA 79:927-930

33. Sumoski W, Baquerizo H, Rabinovitch A (1989) Oxygen free radical scavengers protect rat islet cells from damage by cytokines. Diabetologia 32: 792-796

34. Hammonds P, Beggs M, Beresford G, Espinal J, Clarke J, Mertz RJ (1990) Insulin-secreting $\beta$-cells possess specific receptors for interleukin-1 $\beta$. FEBS Lett 261: 97-100

35. Buscema M, Vinci C, Rabuazzo M, Forte F, Caltabiano V, Squatrito S, Purello F (1990) Nicotinamide improves insulin secretion in islets unresponsive after chronic exposure to IL-1 $\beta$. Diabetologia 33 [Suppl]: A18 (abstract)

36. Sargent CA, Dunham I, Trowsdale J, Campbell RD (1989) Human major histocompatibility complex contains genes for the major heat shock protein HSP70. Proc Natl Acad Sci USA 86: $1968-1972$

37. Wurst W, Benesch C, Drabent B, Rothermel E, Benecke B, Günther $E$ (1989) Localization of heat shock protein 70 genes inside the rat major histocompatibility complex close to class III genes. Immunogenetics 30: 46-49

38. Thomsen M, Mølvig J, Zerbib A et al. (1988) The susceptibility to insulin-dependent diabetes mellitus is associated with $\mathrm{C} 4$ allotypes independently of the association with HLA-DQ alleles in HLA-DR3, 4 heterozygotes. Immunogenetics 28: 320-327

39. Pociot F, M $\varnothing$ lvig J, Wogensen L, Milner C, Campbell, Nerup J (1990) Insulin-dependent diabetes - a polygenic disease? Implications of tumor necrosis factor $\beta$ and heat shock protein 73 polymorphisms. Diabetologia 33 [Suppl]: A83 (abstract)

40. Todd JA, Bell JI, McDevitt HO (1987) HLA-DQ $\beta$ gene contributes to susceptibility and resistance to insulin-dependent diabetes mellitus. Nature 329: 599-604

Received: 12 July 1990

and in revised form: 22 October 1990

Dr. J. Nerup

Steno Memorial Hospital

Niels Steensens Vej 2

DK-2820 Gentofte

Denmark 